\title{
Hydrobiologia
}

\section{When do beetles and bugs fly? A unified scheme for describing seasonal flight behaviour of highly dispersing primary aquatic insects \\ --Manuscript Draft--}

\begin{tabular}{|c|c|}
\hline Manuscript Number: & HYDR7301R3 \\
\hline Keywords: & $\begin{array}{l}\text { flight behaviour, seasonal patterns, year-long dispersal, polarotaxis, Coleoptera, } \\
\text { Heteroptera }\end{array}$ \\
\hline \multicolumn{2}{|l|}{$\begin{array}{l}\text { Corresponding Author Secondary } \\
\text { Information: }\end{array}$} \\
\hline First Author: & Pál Boda \\
\hline \multicolumn{2}{|l|}{ First Author Secondary Information: } \\
\hline \multirow[t]{2}{*}{ Order of Authors: } & Pál Boda \\
\hline & Zoltán Csabai \\
\hline \multicolumn{2}{|c|}{ Order of Authors Secondary Information: } \\
\hline Abstract: & $\begin{array}{l}\text { Changes of seasonal dispersal flight were investigated based on a wide spectrum of } \\
\text { aquatic Heteroptera and Coleoptera species. We hypothesized that species or groups } \\
\text { of species can be characterized by various seasonal patterns of dispersal flight. } \\
\text { Dispersal activity was studied in a lowland marsh located in NE Hungary during a 30- } \\
\text { week long monitoring period. Insects were attracted to highly polarizing horizontal } \\
\text { shiny black plastic sheets laid onto the ground. There are no periods of the year (from } \\
\text { April till October) when insects are not rising into the air, but species have various } \\
\text { seasonal flight activity. Dispersal flight activity of } 45 \text { species could be described. These } \\
\text { activities assessed based on a seasonal approach and proportional classification. } \\
\text { Based on these results three seasonal patterns and twelve sub-patterns were defined. } \\
\text { Comparing the observed patterns with previously reported dispersal activity data, we } \\
\text { argue that observations found in the literature fit well with patterns defined here, } \\
\text { therefore, to assess the dispersal behaviour a unified scheme can be established. Due } \\
\text { to this unified scheme the seasonal dispersal activity of primary aquatic insects } \\
\text { observed in different studies becomes highly comparable. This scheme can be a useful } \\
\text { tool for assessing dispersal behaviour of insects across other geographic regions. }\end{array}$ \\
\hline
\end{tabular}

Response to Reviewers: 


\begin{abstract}
:
Changes of seasonal dispersal flight were investigated based on a wide spectrum of aquatic Heteroptera and Coleoptera species. We hypothesized that species or groups of species can be characterized by various seasonal patterns of dispersal flight. Dispersal activity was studied in a lowland marsh located in NE Hungary during a 30-week long monitoring period. Insects were attracted to highly polarizing horizontal shiny black plastic sheets laid onto the ground. There are no periods of the year (from April till October) when insects are not rising into the air, but species have various seasonal flight activity. Dispersal flight activity of 45 species could be described. These activities assessed based on a seasonal approach and proportional classification. Based on these results three seasonal patterns and twelve sub-patterns were defined. Comparing the observed patterns with previously reported dispersal activity data, we argue that observations found in the literature fit well with patterns defined here, therefore, to assess the dispersal behaviour a unified scheme can be established. Due to this unified scheme the seasonal dispersal activity of primary aquatic insects observed in different studies becomes highly comparable. This scheme can be a useful tool for assessing dispersal behaviour of insects across other geographic regions.
\end{abstract}


1 When do beetles and bugs fly? A unified scheme for describing seasonal flight behaviour of highly

2 dispersing primary aquatic insects

3

4 Boda, $\mathbf{P}^{\mathrm{a}, *}$ - Csabai, $\mathbf{Z}^{\mathrm{b}}$

6 a Department of Tisza River Research, Balaton Limnological Institute, Centre for Ecological Research,

7 Hungarian Academy of Sciences, Bem tér 18/c, H-4026 Debrecen, Hungary

8

$9{ }^{\mathrm{b}}$ Department of Ecology and Hydrobiology, Institute of Environmental Sciences, Faculty of Sciences, University 10 of Pécs, Ifjúság útja 6, H-7624 Pécs, Hungary

* Corresponding author, e-mail: boda.pal@ okologia.mta.hu

\section{Abstract:}

15 Changes of seasonal dispersal flight were investigated based on a wide spectrum of aquatic Heteroptera and

16 Coleoptera species. We hypothesized that species or groups of species can be characterized by various seasonal patterns of dispersal flight. Dispersal activity was studied in a lowland marsh located in NE Hungary during a 30-week long monitoring period. Insects were attracted to highly polarizing horizontal shiny black plastic sheets laid onto the ground. There are no periods of the year (from April till October) when insects are not rising into the air, but species have various seasonal flight activity. Dispersal flight activity of 45 species could be described. These activities assessed based on a seasonal approach and proportional classification. Based on these results three seasonal patterns and twelve sub-patterns were defined. Comparing the observed patterns with previously reported dispersal activity data, we argue that observations found in the literature fit well with patterns defined here, therefore, to assess the dispersal behaviour a unified scheme can be established. Due to this unified scheme the seasonal dispersal activity of primary aquatic insects observed in different studies becomes highly comparable. This scheme can be a useful tool for assessing dispersal behaviour of insects across other geographic regions.

Keywords: flight behaviour, seasonal patterns, year-long dispersal, polarotaxis, Coleoptera, Heteroptera 
Overwintering, mating and deposition of eggs in suitable aquatic habitats are instinctive goals for aquatic insects (Bohonak \& Jenkins 2003). To be in the most suitable habitat in each period of their life cycle, aquatic beetles and bugs shuttle among these habitats by flight according to their 'colonization cycle' denoted by Fernando \& Galbraith (1973). Flight is not the only but the most effective way of dispersal (Bilton et al. 2001) and be an important prerequisite of survival in both individual and population level (Landin 1980). Indirectly, dispersal flight is important from conservation biological (Eyre 2006), and evolutionary points of view (Wagner \& Liebherr 1992). Thus, understanding this kind of dispersal behaviour of aquatic insects is an old goal for ecologists.

The phenomenon of the dispersal flight, as a result of complex processes is driven and influenced by many biotic and abiotic factors: e.g. elevation of the sun which determines the polarotactic detectability of water surfaces (Csabai et al. 2006), air temperature (Weigelhofer et al. 1992), water temperature (Popham 1953, Pajunen \& Jansson 1969), wind speed (Pajunen \& Jansson 1969, Csabai \& Boda 2005), rain, reproductive status (Boda \& Csabai 2009a), density (Yee et al. 2009, Pajunen \& Pajunen 2003), actual state and changing of the original habitat (food sources, decrease of the water level, amount of predators, etc.) as noted by Nilsson \& Svensson 1992, Ohba \& Takagi 2005, Yee et al. 2009, for example. Almost all of these factors are continuously changing in time; many of them are changing between well defined thresholds through different seasons. All of the environmental factors together have a well defined seasonal rhythm, and it clearly defines the possibilities and needs of dispersal flight, so they must have a seasonal rhythm, too. If this is so, the most useful approach to describe the year-long changes of dispersal flight would be a season-based one.

Many authors have investigated the flight of aquatic beetles and bugs and the literature is rich with useful information and data about the seasonal changes of aerial dispersal. Some authors tried to describe the changes of the dispersal behaviour during longer periods than one season (Thomas 1938, Leston \& Gardner 1953, Brown 1954, Fernando 1958, Richard 1958, Young 1966, Pajunen \& Jansson 1969, Benedek \& Jászai 1972, Fernando \& Galbraith 1973, Landin 1980, Bagge 1982, Van der Eijk 1987, Behr 1990, Weigelhofer et al. 1992, Nilsson 1997, Lundkvist et al. 2002, Miguélez \& Valladares 2008), while others noted only some clearly visible peaks of dispersal activity (Popham 1964, Williams 1987, Davy-Bowker 2002) or just noted that the dispersal flight occurred in warmer days without strong wind (Richardson 1907, Macan 1939, Poisson et al. 1957). Generally, the objects of these investigations are restricted to only a few species. Moreover, most of the 60 former studies were conducted by using light traps (e.g. Benedek \& Jászai 1972, Zalom et al. 1980, Weigelhofer 
et al. 1992), but in these cases only the evening and the night flight are observable, which is important but only a short part of the daily flying period. In colder seasons of the year (spring and autumn) no dispersal activity could be observed during night flights mainly due to the lower evening and night air temperature, although the dispersal flight can be remarkable during daytime in these seasons too (Csabai et al. 2012). Applying the lighttrap method we cannot draw reasonable conclusions about the rhythm of the year-long dispersal flight. There are some methods, which might be proper to follow up year-long dispersal behaviour such as mark-recapture methods (Pajunen \& Jansson 1969, Davy-Bowker 2002, Pajunen \& Pajunen 2003), water filled trays, tanks or pools (Fernando \& Galbraith 1973, Behr 1990, Lundkvist et al. 2002, Boix et al. 2011), but these techniques require huge sampling efforts to studying dispersal flight throughout the year. Strictly because of the above mentioned shortcomings just some of these papers (Pajunen \& Jansson 1969, Fernando \& Galbraith 1973, Landin 1980, Behr 1990, Nilsson 1997, Lundkvist et al. 2002, Miguélez \& Valladares 2008) treated and tried to describe the real seasonal rhythm of dispersal flight. Additional dispersal-based studies focused not on seasonal dispersal activity but on other strongly specified questions, which are only marginally affected by seasonal dispersal flight.

Summarized, many details of the seasonal dispersal flight of certain species have become known thanks to former studies conducted by variously applied methods. However these data were episodic and no one has yet tried to integrate the accumulated knowledge into a comprehensive scheme.

The aim of our work was to describe the dispersal flight activity of a wide spectrum of aquatic insects all day long on every week during a whole year period. We hypothesized that species (or group of species) can be characterized by different yearly rhythms of dispersal flight. Based on the annual flight data of a wide spectrum of species we proposed here a new unified scheme with seasonal approach for classification and description of seasonal dispersal flight. Finally, in spite of the methodological incongruence, we tried to insert the previously published results into the scheme.

\section{Material and methods}

Study site: Our study area was in north-eastern Hungary, in the territory of Hortobágy National Park, in the area of the Egyek-Pusztakócs Marsh System, at the shore of Hagymás-basin marsh (47³3'29” N, 2055'29” E; $10 \mathrm{~km} \times 10 \mathrm{~km}$ UTM grid code: DT 96). It lies in a semiarid-semihumid climatic region, where average yearly air temperature is $9.8-9.9^{\circ} \mathrm{C}$. Average yearly precipitation is $520-550 \mathrm{~mm}$, and most of that falls in spring and autumn. The area of the Hagymás-basin was approximately $0.3 \mathrm{~km}^{2}$ with depth up to $80 \mathrm{~cm}$. The marsh was 
characterized by various and extremely patchy vegetation, and consequently by rich and diverse aquatic beetle and bug assemblages (Csabai et al. 2005). During the sampling period the water level of the marsh was more or less permanent, because of the continuous water supply from floods and rainfalls.

Theoretical basis of the sampling method: Almost all aquatic insects are capable of detecting polarised light (Horváth \& Varjú 2004, Kriska et al. 2007, Horváth et al. 2011). Aquatic beetles and bugs can also find new habitats by means of the horizontal polarization of light reflected from the water surface (Schwind 1991). Shiny surfaces (e.g. car bonnets, black plastic sheets used in agriculture, vertical glass surfaces) - from which the direction and the degree of the polarized light is similar to that of the light reflected from water surfaces - may confuse polarotactic water insects, since they detect them as horizontally polarizing water surfaces (Horváth 1995). Therefore aquatic insects can be trapped by using these artificial surfaces (Bernáth et al. 2001).

Sampling period, method and elaboration: In the light of climatic and meteorological conditions in Hungary and their effects on the seasonal flight activity and phenology of primary aquatic insects (e.g. Boda \& Csabai 2009a, 2009b), samples were taken altogether on 30 sampling weeks, from $14^{\text {th }}$ week (beginning of April) until $43^{\text {rd }}$ week (end of October) in 2005. Aquatic insects were collected for 24 hours on every week separated hourly. Sampling began every Wednesday at 8 a.m. (Local summer time: UTC +2 ), regardless of weather conditions and was carried out until the next morning (8 a.m.). Aquatic insects were trapped on three black agricultural plastic sheets (foils) laid onto the ground, all of them were $9 \mathrm{~m} \times 3 \mathrm{~m}$ in size. During the sampling period several such plastic sheets were used, their order was changed randomly. These test surfaces were placed $40 \mathrm{~m}$ apart from each other, and $30 \mathrm{~m}$ from the water margin. Using insect aspirators, water bugs and beetles that landed on the test surfaces were collected continuously by manual sampling. Individuals from the test surfaces were put into separate bottles hourly, which were labeled by the code of the surface and the time and date of collection. Collected animals were preserved in $70 \%$ ethanol. Beetles were identified under stereomicroscope in the laboratory using keys and descriptions by Csabai (2000) and Csabai et al. (2002). Aquatic bugs were identified using keys by Jansson (1986), Savage (1989) and Soós et al. (2009). Dryops spp., Hydrochus spp. and Helophorus spp. taxa were identified only to genus level.

Evaluation: Despite the hourly separated samples, daily pooled data were used during evaluation. There were no significant differences among the catch efficiencies of the sheets (Csabai et al. 2012), hence the data originating from the three sheets were grouped together in the evaluation. Those sampling days, when the weather conditions (strong wind and rain) inhibited or extremely decreased the dispersal flight $-16^{\text {th }}, 18^{\text {th }}$ and 
$12123^{\text {rd }}$ weeks - were ignored and excluded from the evaluation. There were two notable altering dates in the 122 composition of the flying assemblage [numbers of individuals of each species (see details in Csabai et al. 2012)].

123 The first such date was on the $21^{\text {st }}$ week, and another one was in the $35^{\text {th }}$ week. These two dates show high 124 coincidence with the turning points of the seasons. Hence, seasonal approach with two stages was used to 125 analyze the data and define the main dispersal periods. The characteristic of dispersal flight in case of a given species can be assessed as proportion of the maximal dispersal flight activity. Hence, the comparison will be

127 relevant in cases of various regions and in cases of certain species by the help of this percentile approach.

128 Maximal dispersal activity of species can be observed solely in one season, with a global peak of activity. This 129 global peak with maximal number of individuals was regarded as $100 \%$ of the dispersal activity and further activity peaks were expressed as a percentage of this global peak. Besides the maximal dispersal peak, there 131 might be lower but clearly visible peak(s) of flight activity in another season or seasons. If these additional peaks reached at least $20 \%$ of the maximal flight activity, it was considered as a significant local peak. Namely, the

133 season of the maximal dispersal activity with the global peak may define the 'seasonal dispersal main pattern'; moreover local peak(s) of dispersal activity or its absence may correspond to the 'seasonal dispersal sub-pattern'.

135 Relations of the local peaks to each other were not taken into consideration in the sub-pattern stage because of their high variability and less importance. Thereby, spring (SP), summer (SU) and autumn (AU) main patterns

137 and related sub-patterns are evolved (Table 1 and 2). The naming process follows the evaluation stages as three138 code signs. Namely, the code written in capital letters means the abbreviation of the main pattern (SP, SU or $139 \mathrm{AU}$ ), the other codes with small letters refers to the sub-patterns (sp, su, au). The order of the codes follows the 140 natural order of seasons. For example, sp-SU-au means that the highest flight activity peak can be found during 141 summer and additional local peaks are visible during spring and autumn, of which either local peak can be higher 142 or lower. ' 0 ' code was used when one or both of the additional local peaks were absent such as in the following 143 cases for example: 0-SU-0 means maximal activity in summer and no significant dispersal flight during spring 144 and autumn; sp-0-AU means maximal activity in autumn and local peak(s) can be found only in spring, but not 145 during summer; or SP-0-au means highest dispersal activity in spring, no notable flight in summer but local 146 peak(s) present during autumn. All possible combinations of patterns and sub-patterns according to the seasons 147 with a short description of each combination were summarized in Table 2. All of the common species can be 148 placed into one combination of the patterns and sub-patterns with no doubt, but below 100 captured individuals, 149 the flight dynamics might be formed by coincidental occurrences, hence dispersal patterns of these less common 150 species were assigned as questionable. To prove the soundness of the scheme based on the percentile approach 
151 we used non-metric multidimensional scaling (NMDS) ordination with Euclidean distances. Dispersal 152 characteristics of all common species were included in the analyses; as variables the percentage share of 153 dispersal peaks were used. On the scattergram, species of each main pattern were denoted by convex hulls, while 154 sub-patterns were signed with different symbols.

\section{Results} individuals, 21 taxa) were captured (Table 1). The collected species are common inhabitants of both temporary and permanent waters and they are generally good fliers (Savage 1989, Nilsson \& Holmen 1995). Dispersal flight of aquatic insects was observed from April till October with various numbers of individuals and species

\section{1 (Figure 1).}

Generally, the species showed different activity in the seasons (Table 1). Based on the two stages

163 seasonal approach, we observed all of the three possible main patterns and 10 sub-patterns of the 12 possible

164 ones (Figure 2 A-I). All possible and realized combinations of patterns and sub-patterns according to the seasons

165 were listed in Table 2. Based on the captured numbers of individuals, 22 species were regarded as common species ( $\mathrm{n}>100)$ and in these cases the classification could be done without doubt. The dispersal pattern/subpattern could be assigned with relatively high certainty to 23 species $(10<\mathrm{n}<100)$, but the classification was still questionable. Further 45 species cannot be classified to any seasonal pattern because of the small numbers of individuals $(\mathrm{n}<10) .29$ of 45 more common species flew during all of the three seasons, 14 species occurred in two seasons only, while two were noticed only in one season (Table 1).

172 the most popular season for flight. There were no species - except some with extreme low numbers of 173 individuals $(\mathrm{n}<10)$ - which did not fly in summer. 17 species followed the spring (SP) and only four species 174 followed the autumn (AU) main-patterns. Within the spring main pattern (SP), the most frequent sub-patterns 175 were the SP-0-0 and SP-su-0 sub-patterns, both followed by 8 species. There was only one species which flew 176 according to SP-0-au sub-pattern. Within the summer main pattern (SU), the 0-SU-0 sub-pattern was preferred 177 the most (16 species), but 2-2 species flew according to the 0-SU-au sub-pattern and the sp-SU-au sub-pattern.

178 Although, sp-SU-0 sub-pattern had 4 follower species, but all of them were less common species $(10<\mathrm{n}<100)$, so 179 in these cases the classifications were questionable. Among the three species, which flew en masse in autumn, 
one followed the 0-0-AU sub-pattern, one the sp-0-AU sub-pattern, and one the 0-su-AU sub-pattern; moreover

181 the later one has further follower species with lower number of individuals.

During the evaluation we revealed that there might be two more sub-patterns theoretically (Table 2). In

183

184

185

186

187

188

189

190

191

192

193

194

195

196

197

198

199

200

201

202

203

204

205

206

207

208

209

spite of that, we could not find species which flew in spring like SP-su-au sub-pattern and in autumn as sp-suAU sub-pattern. Namely, there were no species in our study which flew en masse during all the three seasons and the maximal dispersal activity was in spring or autumn. Based on the theoretical background of the scheme, the realness of the hypothetic sub-patterns are highly presumptive. Even if these sub-patterns were considered theoretical, we treated them as genuine parts of the scheme.

Based on the NMDS ordination, the dispersal flight characteristics in case of the common species were truly different in pattern and sub-pattern levels, the scattergram clearly shows that species were classified to different patterns and sub-patterns were highly separated each other (Figure 3). The species formed three wellseparated groups according to the main patterns, the sub-patterns also separated well within these groups.

\section{Discussion}

It is notable, that aquatic insects achieve dispersal flight in any period of the year, but its extent and duration have remained poorly understood in the majority of primary aquatic insect species. We used an adequate new sampling method (Csabai et al. 2006, 2012) to follow up the seasonal changes of dispersal flight. A unified scheme was established based on seasonal dispersal activity of 45 species to assess the types of seasonal dispersal behaviour. In the first stage spring, summer and autumn seasonal dispersal main patterns were observed. In general, we found that there are no periods from the beginning of April till the end of October, when aquatic insects are not rising into the air. Most of the species flew in maximal number of individuals in summer. This is highly consistent with the results of all former studies (Table 3), but we revealed that there are several species which flew 'en masse' in spring and autumn. Dispersal flight in spring and autumn were mentioned in former publications, but rarely assigned as maximal peaks of activity. The optimal flying periods are shorter in spring and autumn than summer because of the rainfall and the lower air temperature (Csabai et al. 2012). In spite of this, a lot of species show maximal dispersal activity during either of these colder periods. In the second stage we described 12 sub-patterns all together. The common marsh dwelling species utilized nine of them in Hungary; hence these are treated as realized sub-patterns. One further sub-pattern exists with only some species and low numbers, so the presence of this sub-pattern can be not clearly revealed in our region. There are two more sub-patterns (SP-su-au, sp-su-AU) marked as theoretical sub-patterns which were not realized during 
our sampling period and/or among these marsh-dwelling species in Hungary. Naturally, there might be followers

211 for these sub-patterns at different habitats and/or in different geographical areas.

General conclusions about the dispersal or concrete seasonal peaks of dispersal flights were described by many authors using various sampling methods. But only those dispersal-based studies pointed out the

214 seasonal changes of dispersal flight, in which the sampling periods covered three seasons and the sampling 215 frequency was strictly regular (Table 3). Based on these papers, the first period of dispersal flight might occur 216 during April and May. Generally, both the mass and maximal dispersal flights were observed in the summer 217 months. From September to the end of October only a low number of individuals were collected. Respectively, 218 several exact seasonal flight periods and peaks of dispersal activity were mentioned by these authors, but the 219 differences between the extents of peaks were never taken into consideration. Without the assessment of the 220 relationship among the peaks it is hard to draw exact conclusions about the seasonal changes of dispersal 221 behaviour. We are not only considering the extent of the peaks, but this is also the basis of the scheme. Despite 222 that our scheme was established based on a Hungarian pilot study, the classification is widely and generally applicable to characterize the seasonal dispersal flight of primary aquatic insects. To demonstrate this, we 224 selected some former studies in which the sampling periods were more than seven months (covering three seasons) and reported high numbers of collected individuals, moreover the changes of the dispersal activity are traceable and the applied method is adequate to study the seasonal dispersal rhythm (Table 4). Six of these seven studies investigated the seasonal flight periods of aquatic beetles, whereas only one paper dealt with this kind of activity of aquatic bugs. Reviewing these studies well-defined seasonal dispersal description can be found in cases of 19 species. Unfortunately there are only three aquatic beetle species which were common both among results of these studies and in our checklist and further three aquatic beetle species were common among the cited papers (Table 4). In the case of these species, strong differences in the seasonal patterns could have been caused by a few factors.

1. Geographic differences: In case of Anacaena limbata, Fernando \& Galbraith (1973) mentioned an

234 SU main pattern with various sub-patterns (sp-SU-0 or sp-SU-au) in Canada, but we observed this species as a 235 typical spring flyer (SP-0-0). Both classifications are based on many data (more than 500 individuals), hence the 236 classifications are not questionable. The spring dispersal period was observed in the dispersal behaviour in both 237 regions. The climate of the Canada might have formed the various seasonal dispersal behaviours, and suppressed 238 the spring dispersal to the sub-pattern level. Similar mechanisms might have formed the pattern and sub-patterns 239 of Agabus bipustulatus. According to Behr (1990) and Lundkvist et al. (2002), A. bipustulatus had two active 
240 periods during the year. The first period was in summer months and the second was during October. In Germany 241 (Behr 1990), the maximal activity was observed in summer with a feasible peak in autumn (0-SU-0 or 0-SU-au), 242 while in Sweden (Lundkvist et al. 2002) the species had 0-su-AU sub-pattern. Most probably, the same effect 243 might be seen according to the changes of the altitude. Unfortunately, there are no results about this phenomenon 244 in case of aquatic insects, but it is clearly shown in case of terrestrial insects (e.g. Holuša et al. 2006).

2. Number of individuals collected: For example, Hydroporus planus flew according to SP-su-0 sub-

246 pattern in Hungary, but there are no great difference in the seasonal dispersal percentages in spring and summer 247 (spring: 51,6\%, summer: 41,9\%; Table 1). In Germany, Behr (1990) described this species as a typical summer 248 flyer (0-SU-0), while Lundkvist et al. (2002) in Sweden described two different flight behaviors (0-SU-0 and 0249 SU-au). These differences might be caused by the differences among the collected number of individuals (Behr: 25086 ind., Lundkvist et al.: almost 500 ind., this study: 31 ind.). Our classification might be influenced by the 251 coincidental occurrences because of the smaller number of collected individuals and the almost equal dispersal 252 percentage during two seasons. If three individuals did not fly in the last sampling day of spring, but did in the 253 first sampling day in summer, the main pattern and the sub-pattern could be the same as Behr (1990) and 254 Lundkvist et al. (2002) described. Similar reasons could explain Hydroglyphus geminus being described as 0255 SU-0 or 0-SU-au sub-pattern in Spain based on only 72 specimens (Miguélez \& Valladares 2008), while in 256 Hungary this species had 0-su-AU sub-pattern with no doubt (1926 ind.). These cases strongly support our 257 statement that classification can be done without doubt when the number of individuals are high enough $(\mathrm{n}>100)$, 258 otherwise the patterns must be considered as questionable. Another problem based on numbers of individuals can be arisen during applying our evaluation method, 260 if the sampling intensity was highly uneven among the seasons. If numbers of samples are the same from every 261 season, the activity pattern and coding can undoubtedly considered to be real and appropriate. However, if the 262 numbers of samples from each season are different, it is recommended to introduce a restriction for assessing the 263 seasonal flight activity. Our suggestion that it could be done based on the percentage shares of the samples and 264 numbers of individuals among the seasons. If the percentage distribution of the samples (sampling days) are, for 265 example, spring: $20 \%$ - summer: $60 \%$ - autumn: $20 \%$, the activity pattern can be considered as real and 266 acceptable if the percentage share of the number of individuals of a certain species reach or exceed the share of 267 the samples for that season when the maximum activity peak can be visible (main pattern). So if the global 268 activity peak could be seen in spring and local peaks were observed in summer, the seasonal activity pattern 269 would be SP-su-0; but it can be considered to be real and acceptable if more than $20 \%$ of the individuals were 
caught during spring. If the maximal peak was observed in summer and there were additional peaks in spring (sp-SU-0), the pattern can be correct if at least the $60 \%$ of the individuals were captured in summer. If this criterion is not satisfied the stated pattern should be regarded as questionable, even if it is based on high number of individuals. In our study the percentage distribution of the samples (sampling days) among the seasons was 7

$274(23,33 \%)-13(43,33 \%)-10(33,33 \%)$, respectively. Based on this, all common species met the criterion and produced significantly higher proportion (Table 1) than the share of samples in that season when the maximal dispersal peak was manifested.

3. Taxonomic resolution: Helophorus brevipalpis were mentioned by Landin (1980) from Sweden and by Miguélez \& Valladares (2008) from Spain as a summer species, but whereas Miguélez \& Valladares (2008) described a local peak in spring (sp-SU-0), Landin (1980) found it only in summer (0-SU-0). Landin \& Stark (1973) previously mentioned that H. brevipalpis occurs in September in Sweden, but they only followed dispersal flight during a short period. In the present study, Helophorus individuals were identified only to genus level, and flew 'en masse' in summer, but further local peaks can be seen in the other seasons. Further analyses with better taxonomic resolution are needed before making conclusions about these comparisons for $H$. brevipalpis.

4. Unidentified reasons: Hydroporus incognitus were described as 0-SU-au species in Sweden by Nilsson (1997), with high numbers of individuals in September. In Germany, Behr (1990) described $H$. incognitus as a typical summer species (0-SU-0). The flight is pre-reproductive in Sweden and directly following the breeding season in Germany (Nilsson 1997). Later, in Sweden also, Lundkvist et al. (2002) found 0-SU-au sub-pattern during the first sampling year, but in the second year the local peak occurred in spring (sp-SU-0). In both years, the local peaks were near to the global peak. Based on this, the explanation of Nilsson might be reconsidered. In fact, $H$. incognitus has a very high dispersal activity throughout the year where it is found.

In summary, we described the results of a mensurative experiment, established a frame scheme and inserted all previously known results into the frames. Our scheme is likely in accordance with the natural

294 phenomenon. Namely, there might be several main periods of dispersal flight based on likely reasons of why the aquatic insects arise to the air. The 'colonization cycle' - habitat selection for different purposes during life cycle - determines the main periods of dispersal flight, and it can be further divided based on the purpose of the flight - breeding-, hibernation-, aestivation- and feeding-flight as noted by Fernando \& Galbraith (1973). In Europe, the breeding flight generally occurs in spring and early summer. In summer, the purposes of the dispersal flight are to find suitable habitat for feeding or aestivation. In this period the starting of dispersal flight is primary 
300 influenced by the condition of habitats and stochastic ecological conditions as noted by Popham (1964). In

301 autumn, most of the species are looking for a suitable habitat for overwintering (Fernando \& Galbraith 1973).

302 Whatever is the reason, the phenology features and the environmental factors (e.g. rainfall, water loss, increased

303 water and air temperature, high predation pressure, food shortage) together affect the realized flying periods. It

304 follows that these periods are species and geographically dependent. The turning point of the seasons might be

305 different based on the latitude. If this is so, the dispersal behaviour of a given species might be different in

306 different geographical areas, as Pajunen \& Jansson (1969), Benedek \& Jászai (1972), Lundkvist et al. (2002) and

307 Boda \& Csabai (2009a) previously mentioned.

308 All the data from previous studies about the dispersal flight originated from the temperate zone of

309 Europe and North America; the scheme is useable in these regions yet. Naturally, winter season may play a

310 significant role in forming seasonal dispersal flight in warmer climates, for example the south part of the

311 Mediterranean, subtropical or tropical territories of other continents. Thus, a winter main pattern (WI) and its

312 sub-patterns likely would appear in the scheme and the sub-pattern level might be widened in the future in cases

313 of all other main patterns. The scheme is appropriate for including in new patterns and can be expanded to

314 accommodate future investigations. 


\section{Acknowledgement}

This work was supported by the grant Hungarian Scientific Research Fund (OTKA F-046653). Authors`s thanks are to László Papp, Klára Kecső, Enikő Kovács (University of Debrecen, Hungary) for extensive help during field works. Many thanks to Thomas G. Horvath (SUNY Oneonta, NY USA) for providing

\section{References}

Bagge, P., 1982. Caddies flies and water bugs of small water bodies caught by light trapping in southeastern Finland. Notulae Entomologicae 62: 73-81.

Behr, H., 1990. Untersuchungen zum Flug- und Immigrationsverhalten von Wasserkäfern der Gattung Hydroporus Claiv. (Col.: Dytiscidae). Drosera 90: 77-94.

Benedek, P. \& V.E. Jászai, 1972. On the migration of corixidae (Heteroptera) based on light trap data. Acta Zoologica Academiae Scientarium Hungarici 19: 1-9.

Bernáth, B., G. Szedenics, G. Molnár, Gy. Kriska \& G. Horváth, 2001. Visual ecological impact of "shiny black anthropogenic products" on aquatic insects: oil reservoirs and plastic sheets as polarized traps for insects

Bilton, D.T., 2001. Dispersal in freshwater invertebrates. Annual Review of Ecology, Evolution, and Systematics 32: 159-181.

Boda, P. \& Z. Csabai, 2009a. Seasonal and diel dispersal activity characteristics of Sigara lateralis (Leach, 1817) (Heteroptera: Corixidae) with special emphasis of the possible environmental factors and breeding

Boda, P. \& Z. Csabai, 2009b. Diel and seasonal dispersal activity patterns of aquatic Coleoptera and Heteroptera. state. Aquatic Insects 31: 301-314. Verhandlungen der Internationalen Vereinigung für Limnologie 30: 1271-1274.

Bohonak, A.J. \& D.G. Jenkins, 2003. Ecological and evolutionary significance of dispersal by freshwater invertebrates. Ecology Letters 6: 783-796.

Boix, D., A.K. Magnusson, S. Gascón, J. Sala \& D.D. Williams, 2011. Environmental influence on flight activity and arrival patterns of aerial colonizers of temporary ponds. Wetlands 31: 1227-1240.

Brown, E.S., 1954. Report on Corixidae (Hemiptera) taken by light trap at Rothamstead Experimental Station. Proceedings of the Royal Entomology Society of London (A) 29: 17-22. 
Csabai, Z., 2000. Vízibogarak kishatározója I. (Coleoptera: Haliplidae, Hygrobiidae, Dytiscidae, Noteridae, Gyrinidae). [A guide for the identification of water beetles of Hungary, I. (in Hungarian with English abstract)]. In: Vízi Természet- és Környezetvédelem 15. Környezetgazdálkodási Intézet, Budapest.

Csabai, Z. \& P. Boda, 2005. Effects of the wind speed on the migration activity of aquatic insects (Coleoptera, Heteroptera). Acta Biologica Debrecina Supplementum Oecologica Hungarica 13: 37-42.

Csabai, Z., P. Boda, B. Bernáth, Gy. Kriska \& G. Horváth, 2006. A "polarization sun-dial” dictates the optimal time of day for dispersal by flying aquatic insects. Freshwater Biology 51: 1341-1350.

Csabai, Z., P. Boda, A. Móra \& B. Tóthmérész, 2005. Comparative analysis of aquatic beetle and bug assemblages of sedge stands of an alcalic lowland marsh in Hungary. Verhandlungen der Internationalen Vereinigung für Limnologie 29: 1011-1014.

Csabai, Z., Zs. Gidó \& Gy. Szél, 2002. Vízibogarak kishatározója II. (Coleoptera: Georissidae, Spercheidae, Hydrochidae, Helophoridae, Hydrophilidae). [A guide for the identification of water beetles of Hungary,

Csabai, Z., I. Szivák, Z. Kálmán \& P. Boda, 2012. Diel flight behaviour and dispersal patterns of aquatic Coleoptera and Heteroptera species with special emphasis on the importance of seasons. Naturwissenschaften 99: 751-765.

Davy-Bowker, J., 2002. A mark and recapture study of water beetles (Coleoptera: Dytiscidae) in a group of semi-permanent and temporary ponds. Aquatic Ecology 36: 435-446.

Eyre, M.D., 2006. A strategic interpretation of beetle (Coleoptera) assemblages, biotopes, habitats and distribution, and the conservation implications. Journal of Insect Conservation 10: 151-160.

Fernando, C.H., 1958. The colonization of small freshwater habitats by aquatic insects. 1. General discussion, methods and colonization by the aquatic Coleoptera. Ceylon Journal of Science 1: 117-154.

Fernando, C.H. \& D. Galbraith, 1973. Seasonality and dynamics of aquatic insects colonizing small habitats. Verhandlungen der Internationalen Vereinigung für Limnologie 18: 1564-1575.

Holuša, J., P. Kočárek \& K. Drápela, 2006. Seasonal flight activity of Platycerus caprea (Coleoptera, Lucanidae) in the Moravskoslezské Beskydy Mts (Czech Republic). Biologia 61: 631-633.

Horváth, G., A. Móra, B. Bernáth \& Gy. Kriska, 2011. Polarotaxis in non-biting midges: female chironomids are attracted to horizontally polarized light. Physiology and Behavior 104: 1010-1015. 
Horváth, G. \& D. Varjú, 2004. Polarized Light in Animal Vision - Polarization Patterns in Nature. SpringerVerlag, Heidelberg - Berlin - New York.

Horváth, G., 1995. Reflection-polarization patterns at flat water surfaces and their relevance for insect polarization vision. Journal of Theoretical Biology 175: 27-37.

Jansson, A., 1986. The Corixidae (Heteroptera) of Europe and some adjacent regions. Acta Entomologica Fennica 47: 1-94.

Kriska, Gy., B. Bernáth \& G. Horváth, 2007. Positive polarotaxis in a mayfly that never leaves the water surface: polarotactic water detection in Palingenia longicauda (Ephemeroptera). Naturwissenschaften 94: 148154.

Landin, J., 1980. Habitats, life histories, migration and dispersal by flight of two water-beetles Helophorus brevipalpis and H. strigifrons (Hydrophilidae). Holarctic Ecology 3: 190-201.

Landin, J. \& E. Stark, 1973. On flight thresholds for temperature and wind velocity, 24-hour flight periodicity and migration of the water beetle Helophorus brevipalpis. ZOON Suppl. 1, 105-114.

Leston, D. \& A.E. Gardner, 1953. Corixidae at light: Some records from Sussex, England. Entomologist's Gazette 4: 269-272.

Lundkvist, E., J. Landin \& F. Karlsson, 2002. Dispersing diving beetles (Dytiscidae) in agricultural and urban landscapes in south-eastern Sweden. Annales Zoologici Fennici 39: 109-123.

Macan, T.T., 1939: Notes on the migration of some aquatic insects. Journal of the Society for British Entomology 2: 1-6.

Miguélez, D. \& L.F. Valladares, 2008. Seasonal dispersal of water beetles (Coleoptera) in an agricultural

Nilsson, A.N., 1997: On flying Hydroporus and the attraction of H. incognitus to red car roofs. Latissimus 9: 1216.

Nilsson, A.N. \& B.W. Svensson, 1992. Taking off in cold blood - Dytiscus marginalis flying at $6,4{ }^{\circ}$ C. BalfourBrowne Club Newsletter 50: 1-2.

Nilsson, A.N. \& M. Holmen, 1995. The Hydradephaga of Fennoscandia and Denmark. II. Dytiscidae. Fauna Entomologica Scandinavica 32: 1-286.

Ohba, S. \& H. Takagi, 2005. Food shortage affects flight migration of the giant water bug Lethocerus deyrolli in the prewintering season. Limnology 6: 59-90. 
Pajunen, V.I. \& A. Jansson, 1969. Dispersal of the rock pool corixids Arctocorisa carinata (Sahlb.) and Callicorixa producta (Reut.) (Heteroptera, Corixidae). Annales Zoologici Fennici 6: 391-427.

Pajunen, V.I. \& I. Pajunen, 2003. Habitat selection in rock pool corixids: the effect of local density on dispersal. Hydrobiologia 495: 73-78.

Poisson, R., H. Richard \& G. Richard, 1957. Contribution á l'étude de l'essainmage des Corixidae (Hémiptéres Héteroptéres aquatiques). Vie et Milieu 8: 243-252.

Popham, E.J., 1953. Observations on the migration of Corixids (Hem.) into a new aquatic habitat. Entomologists' Monthly Magazine 89: 124-125.

Popham, E.J., 1964. The migration of aquatic bugs with special reference to the Corixidae (Hemiptera Heteroptera). Archiv für Hydrobiologie 60: 450-496.

Richard, G., 1958. Contribution á l'étude des vols migratoires de Corixidae (Insectes Heteropteres). Vie et Milieu 9: 179-199.

Richardson, N.M., 1907. The migration of aquatic Hemiptera. Entomologists’ Monthly Magazine 43: 105.

Savage, A.A., 1989. Adults of the British aquatic Hemiptera Heteroptera: a key with ecological notes. In: F.B.A. Scientific Publication 50. Freshwater Biological Association, Ambleside.

Schwind, R., 1991. Polarization vision in water insects and insects living on a moist substrate. Journal of Comparative Physiology 169: 531-540.

Soós, N., P. Boda \& Z. Csabai, 2009. First confirmed occurrences of Notonecta maculata and N. meridionalis (Heteroptera: Notonectidae) in Hungary with notes, maps, and a key to the Notonecta species of Hungary. Folia Entomologica Hungarica 70: 67-78.

Wagner, D.L. \& C. Liebherr, 1992. Flightlessness in insects. Trends in Ecology and Evolution 7: 216-220.

Weigelhofer, G., W. Weissmair \& J. Waringer, 1992. Night migration activity and the influence of meteorological parameters on light-trapping for aquatic Heteroptera. Zoologischer Anzeiger 229: 209218.

Williams, DD., 1987. The Ecology of Temporary Waters. Croom Helm, London.

Yee, D.A., S. Taylor \& S.M. Vamosi, 2009. Beetle and plant density as cues initiating dispersal in two species of adult predaceous diving beetles. Oecologia 160: 25-36.

Young, E.C., 1966. Observations on migration in Corixidae (Hemiptera: Heteroptera) in Southern England. Entomologists’ Monthly Magazine 101: 217-229.

Zalom, F. G., A.A. Grigarick \& M. O. Way, 1980. Diel flight periodicities of some Dytiscidae (Coleoptera) 
434 associated with California rice paddies. Ecological Entomology 5: 183-187.

435 
438 Figure 1 Dispersal activity during the whole sampling period. (A) total number of collected individuals, (B) total 439 number of species. The grey arrows show the sampling days, when the weather conditions inhibited the 440 dispersal.

442 Figure 2 Seasonal dispersal patterns and realized sub-patterns based on the dispersal dynamics of a typical 443 species highlighted in bold. The species included the same pattern and sub-pattern displayed in the diagram, too. 444 (A-C) Spring main pattern (SP), framed up with green (A): Spring sub-pattern (SP-0-0), (B): Spring-summer 445 sub-pattern (SP-su-0), (C): Spring-autumn sub-pattern (SP-0-au). (D-F) Summer main pattern (SU), framed up 446 with red (D): Summer sub-pattern (0-SU-0), (E): Summer-autumn sub-pattern (0-SU-au), (F): Summer-spring447 autumn sub-pattern (sp-SU-au). (G-I) Autumn main pattern (AU), framed up with grey (G): Autumn sub-pattern 448 (0-0-AU), (H): Autumn-summer sub-pattern (0-su-AU), (I): Autumn-spring sub-pattern (sp-0-AU). $20 \%$ of the 449 maximal flight activity was shown by the broken lines as the boundary of the sub-pattern level. The species 450 highlighted in bold are represented in pictures.

452 Figure 3 The differentiation of the dispersal flight behaviour in pattern and sub-pattern levels using non-metric 453 multidimensional scaling (NMDS, final stress $=0.0239)$. 

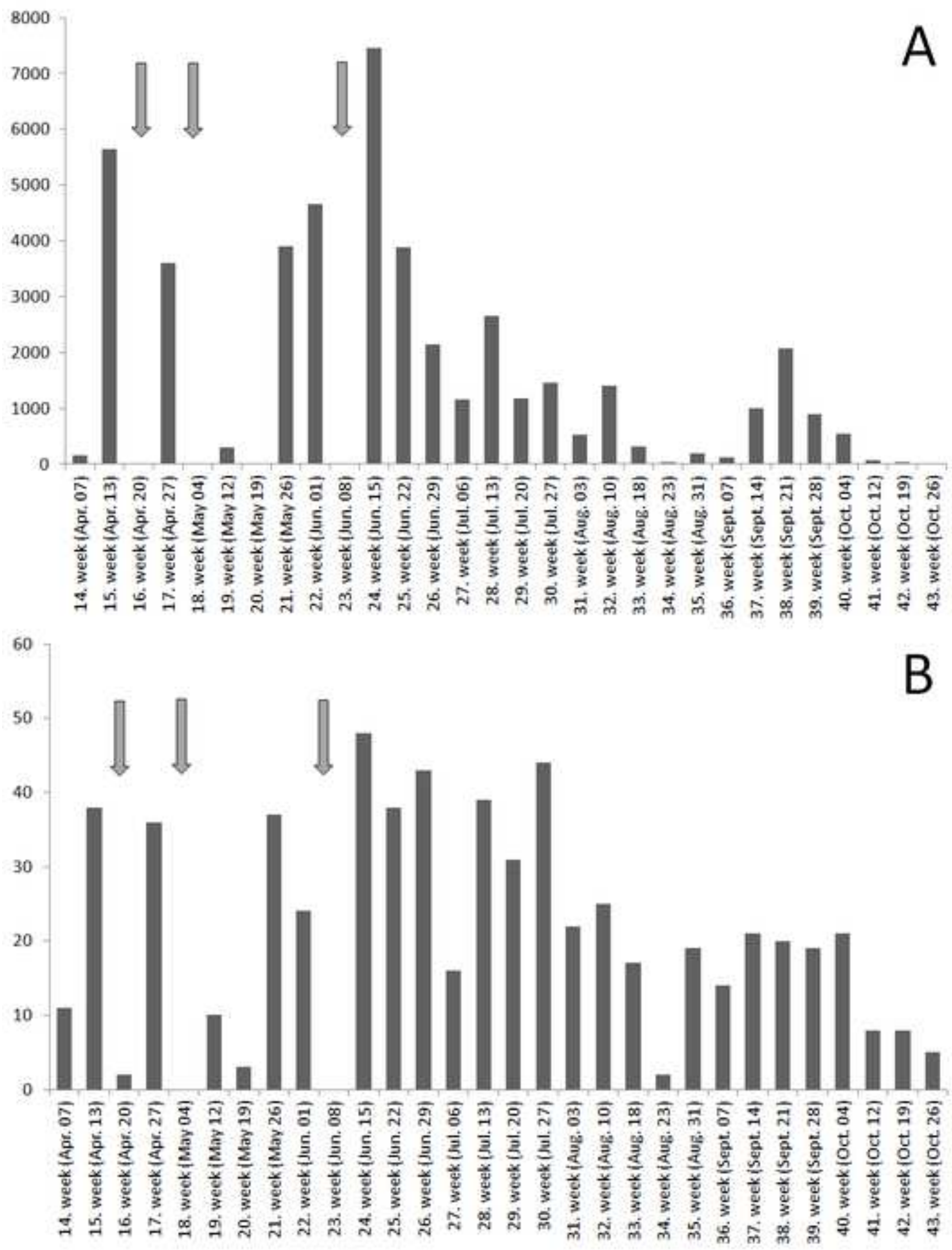


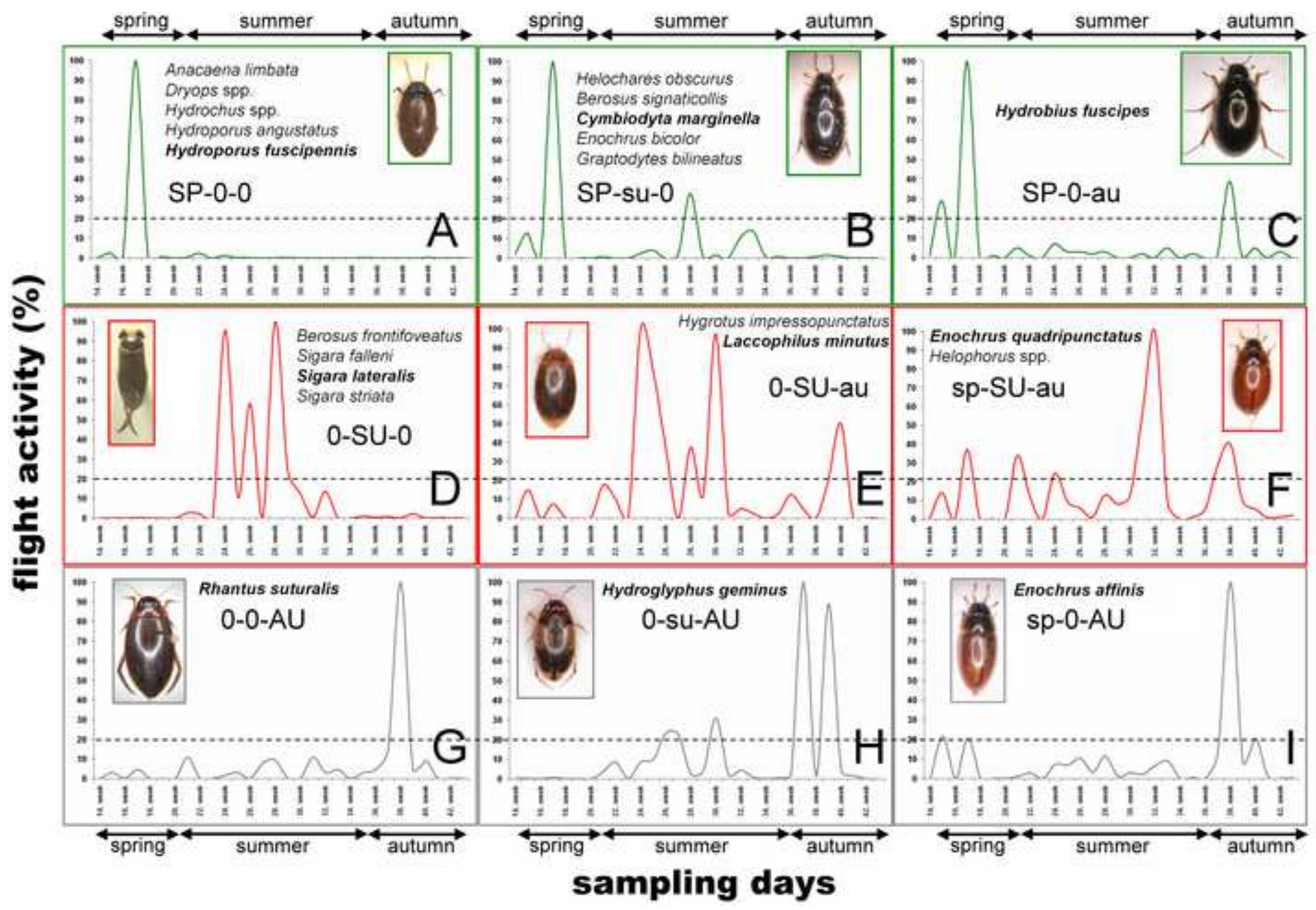




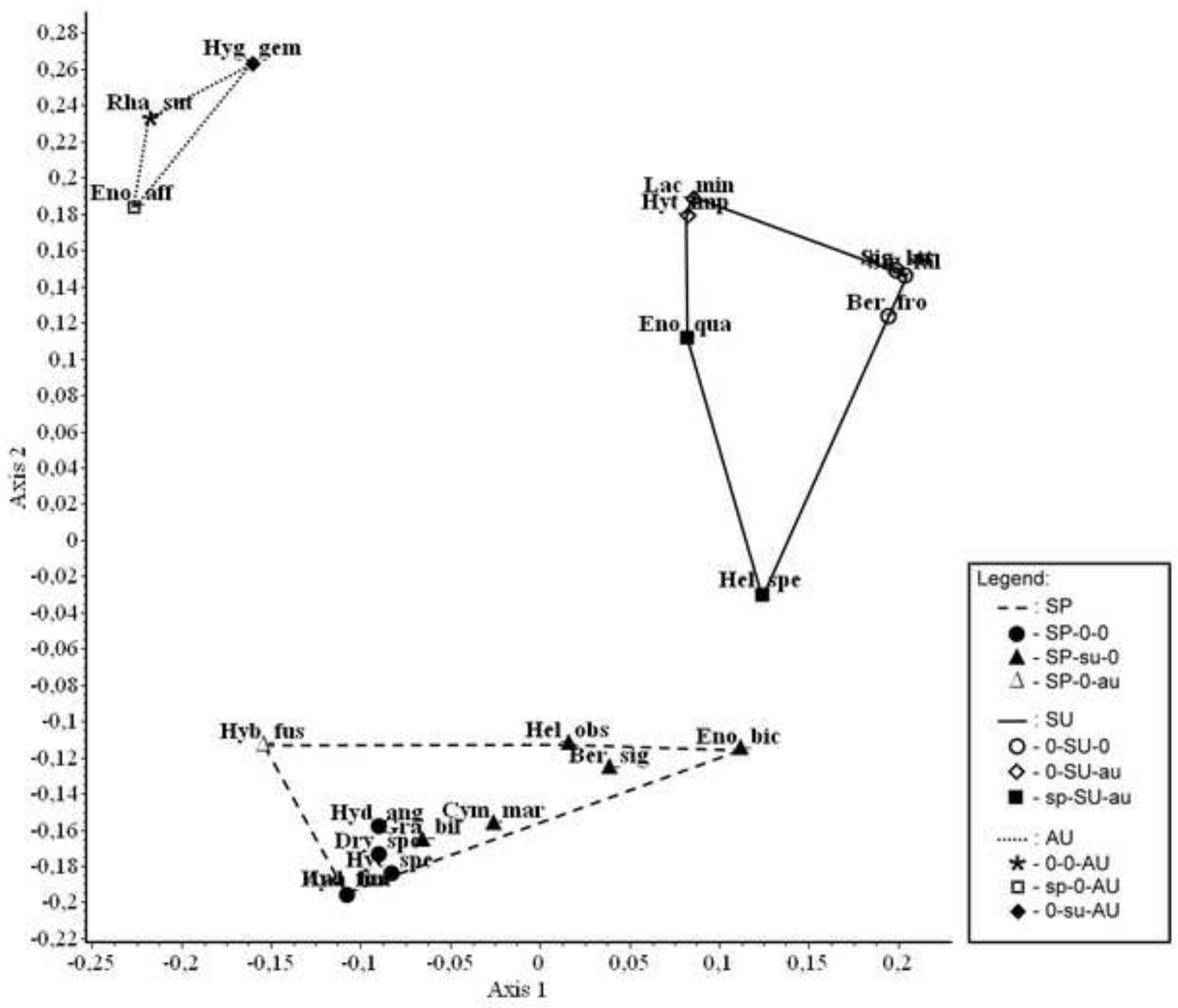


Table 1 Checklist of the collected taxa, percentage distribution of seasonal dispersal activity, total numbers of individuals and seasonal dispersal flight patterns / sub-patterns followed by each species $\left(\mathrm{N}_{\text {total }}\right.$ : numbers of captured individuals during the whole sampling period; *: patterns and sub-patterns are questionable; Abbreviations of the pattern codes as in Figure 2.)

\begin{tabular}{|c|c|c|c|c|c|}
\hline Taxon & $\begin{array}{c}\text { Spring \% } \\
(14-20 . \text { week })\end{array}$ & $\begin{array}{c}\text { Summer \% } \\
(21-33 \text {. week })\end{array}$ & $\begin{array}{c}\text { Autumn \% } \\
\text { (34-43. week) }\end{array}$ & $\mathbf{N}_{\text {total }}$ & $\begin{array}{l}\text { Patterns } \\
\text { and sub- } \\
\text { patterns }\end{array}$ \\
\hline Helophorus spp. & 17,8 & 76,4 & 5,8 & 24590 & sp-SU-au \\
\hline Sigara lateralis (Leach, 1817) & 0 & 98,6 & 1,4 & 3375 & 0-SU-0 \\
\hline Enochrus quadripunctatus (Herbst, 1797) & 12,3 & 66,1 & 21,6 & 3243 & sp-SU-au \\
\hline Helochares obscurus (O.F. Müller, 1776) & 49,8 & 44,7 & 5,5 & 2478 & SP-su-0 \\
\hline Enochrus affinis (Thunberg, 1794) & 17 & 25,8 & 57,2 & 1937 & sp-0-AU \\
\hline Hydroglyphus geminus (Fabricius, 1792) & 0,3 & 37,7 & 61,9 & 1926 & 0 -su-AU \\
\hline Sigara falleni (Fieber, 1848) & 0,1 & 99,8 & 0,1 & 1446 & 0-SU-0 \\
\hline Hydroporus fuscipennis Schaum, 1868 & 84,9 & 15 & 0,1 & 1387 & SP-0-0 \\
\hline Berosus frontifoveatus Kuwert, 1888 & 5,2 & 93,8 & 1 & 730 & 0-SU-0 \\
\hline Hydrochus spp. & 87,2 & 12,8 & 0 & 697 & SP-0-0 \\
\hline Anacaena limbata (Fabricius, 1792) & 92,5 & 6,6 & 0,9 & 548 & SP-0-0 \\
\hline Enochrus bicolor (Fabricius, 1792) & 27,7 & 71,8 & 0,5 & 365 & SP-su-0 \\
\hline Hygrotus impressopuctatus (Schaller, 1783) & 5,3 & 65,1 & 29,5 & 281 & 0-SU-au \\
\hline Graptodytes bilineatus (Sturm, 1835) & 71,4 & 27,4 & 1,2 & 248 & SP-su-0 \\
\hline Cymbiodyta marginella (Fabricius, 1792) & 61,3 & 36,2 & 2,6 & 235 & SP-su-0 \\
\hline Hydrobius fuscipes (Linnaeus, 1758) & 58,5 & 19,2 & 22,3 & 224 & SP-0-au \\
\hline Sigara striata (Linnaeus, 1775) & 0 & 98,6 & 1,4 & 219 & 0-SU-0 \\
\hline Laccophilus minutus (Linnaeus, 1758) & 4,4 & 78 & 17,6 & 205 & 0-SU-au \\
\hline Dryops spp. & 81,3 & 14,1 & 4,7 & 128 & SP-0-0 \\
\hline Rhantus suturalis (MacLeay, 1825) & 4 & 26,4 & 69,6 & 125 & $0-0-\mathrm{AU}$ \\
\hline Hydroporus angustatus Sturm, 1835 & 70,4 & 22,6 & 7 & 115 & SP-0-0 \\
\hline Berosus signaticollis (Charpentier, 1825) & 34,9 & 61,5 & 3,7 & 109 & SP-su-0 \\
\hline Enochrus coarctatus (Gredler, 1863) & 54,8 & 29,8 & 15,5 & 84 & $* \mathrm{SP}-\mathrm{su}-0$ \\
\hline Hesperocorixa linnaei (Fieber, 1848) & 6,3 & 93,8 & 0 & 64 & $* 0-\mathrm{SU}-0$ \\
\hline Agabus uliginosus (Linnaeus, 1761) & 81,7 & 16,7 & 1,7 & 60 & *SP-0-0 \\
\hline Enochrus testaceus (Fabricius, 1801) & 32,1 & 67,9 & 0 & 53 & $* 0-S U-0$ \\
\hline Sigara nigrolineata (Fieber, 1848) & 0,0 & 97,6 & 2,4 & 41 & $* 0-S U-0$ \\
\hline Hydrochara flavipes (Steven, 1808) & 31,6 & 55,3 & 13,2 & 38 & *sp-SU-0 \\
\hline Hygrotus inaequalis (Fabricius, 1776) & 3,0 & 72,7 & 24,2 & 33 & *0-SU-0 \\
\hline Hydroporus planus (Fabricius, 1781) & 51,6 & 41,9 & 6,5 & 31 & $* \mathrm{SP}-\mathrm{su}-0$ \\
\hline Liopterus haemorrhoidalis (Fabricius, 1787) & 83,9 & 16,1 & 0 & 31 & $* \mathrm{SP}-0-0$ \\
\hline Hydrochara caraboides (Linnaeus, 1758) & 76,7 & 13,3 & 10,0 & 30 & *SP-0-0 \\
\hline Limnoxenus niger Zschach, 1788 & 60,0 & 40,0 & 0 & 25 & *SP-su-0 \\
\hline Colymbetes fuscus (Linnaeus, 1758) & 0 & 100,0 & 0 & 24 & $* 0-\mathrm{SU}-0$ \\
\hline Gerris odontogaster (Zetterstedt, 1828) & 20,8 & 58,3 & 20,8 & 24 & $* 0-\mathrm{SU}-0$ \\
\hline Graphoderus austriacus (Sturm, 1834) & 18,2 & 72,7 & 9,1 & 22 & $* 0-\mathrm{SU}-0$ \\
\hline Berosus luridus (Linnaeus, 1761) & 50,0 & 50,0 & 0 & 20 & *sp-SU-0 \\
\hline Haliplus ruficollis De Geer, 1774) & 5,3 & 94,7 & 0 & 19 & $* 0-\mathrm{SU}-0$ \\
\hline Enochrus melanocephalus (Olivier, 1792) & 23,5 & 70,6 & 5,9 & 17 & $* 0-\mathrm{SU}-0$ \\
\hline Callicorixa praeusta (Fieber, 1848) & 6,3 & 93,8 & 0 & 16 & $* 0-\mathrm{SU}-0$ \\
\hline Peltodytes caesus (Duftschmid, 1805) & 43,8 & 53,2 & 0 & 16 & $*_{\text {sp-SU-0 }}$ \\
\hline
\end{tabular}




\begin{tabular}{ccccc}
6,7 & 80,0 & 13,3 & 15 & $* 0-$ SU-0 \\
0,0 & 100,0 & 0 & 14 & $* 0-$ SU-0 \\
23,1 & 76,9 & 0 & 13 & $* 0-$ SU-0 \\
58,3 & 41,7 & 0 & 12 & $*$ SP-0-0 \\
8,3 & 33,3 & 58,3 & 12 & $* 0$-su-AU \\
\hline
\end{tabular}

Paracorixa concinna (Fieber, 1848)

Bidessus nasutus Sharp, 1887

Agabus labiatus (Brahm, 1790)

Hydaticus grammicus (Germar, 1830)

(Thomson, 1878), (7) Gerris argentatus Schummel, 1832, Hydrochara dichroma (Fairmaire, 1892), (6) Cymatia rogenhoferi (Fieber, 1864),

(4) Gyrinus substriatus Stephens, 1829, Hebrus pusillus (Fallén, 1807), Hydaticus seminiger (De Geer, 1774), Hydroporus palustris (Linnaeus, 1761), Notonecta glauca Linnaeus, 1758, (3) Acilius canaliculatus (Nicolai, 1822), Colymbetes striatus (Linnaeus, 1758), Corixa punctata Illiger, 1807, Rhantus frontalis (Marsham, 1802), (2) Acilius sulcatus (Linnaeus, 1758), Corixa affinis Leach, 1817, Graphoderus cinereus (Linnaeus, 1758), Gyrinus paykulli Ochs, 1927, Haliplus immaculatus Gerhardt, 1877, Hydrophilus aterrimus (Eschscholtz, 1822), Hygrotus parallellogrammus (Ahrens, 1812), Ilyocoris cimicoides (Linnaeus, 1758), Porhydrus lineatus (Fabricius, 1775), (1) Cymatia coleoptrata (Fabricius, 1776), Dytiscus circumflexus Fabricius, 1801, Enochrus ochropterus (Marsham, 1802), Gerris lacustris (Linnaeus, 1758), Graptodytes granularis (Linnaeus, 1767), Graptodytes pictus (Fabricius, 1787), Haliplus heydeni Wehncke, 1875, Hesperocorixa sahlbergi (Fieber, 1848), Hygrotus confluens (Fabricius, 1787), Hyphydrus ovatus (Linnaeus, 1761), Ilybius ater (DeGeer, 1774), Ilybius quadriguttatus (Lacordaire, 1835), Laccobius bipunctatus (Fabricius, 1792), Laccobius minutus (Linnaeus, 1758), Noterus clavicornis (De Geer, 1774), Noterus crassicornis (O.F. Müller, 1776), Plea minutissima (Leach, 1817, Rhantus bistriatus (Bergsträsser, 1778), Sigara assimilis (Fieber, 1848), Sigara limitata (Fieber, 1848), Spercheus emarginatus (Schaller, 1783) 
Table 2 All possible and realized combinations of patterns and sub-patterns according to the seasons with a short description of each combination. Abbreviations of the pattern codes as in Figure 2.

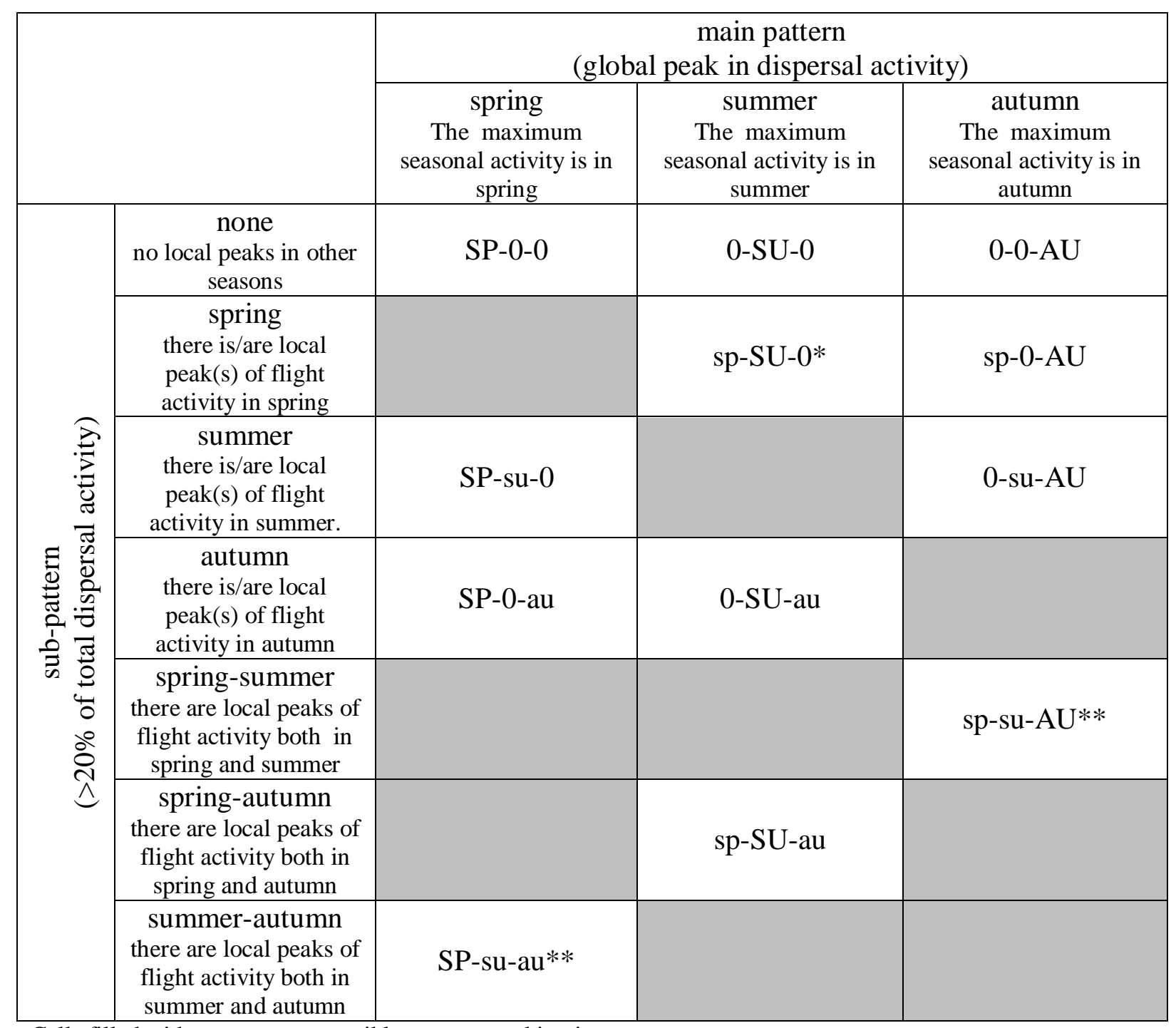

Cells filled with grey are not possible pattern combinations.

*This pattern combination was followed up by only some species which were captured in quite small numbers of individuals, so it was not shown on Figure 2.

** Follower species for this pattern combination were not found in our study. 
Table 3 Summary of published dispersal based studies in which (i) the sampling periods were more than seven months, (ii) the sampling frequency were regular, and (iii) original investigations that provided seasonal dispersal flight conclusions.

\begin{tabular}{|c|c|c|c|c|c|}
\hline Author(s) & Taxa & Method & Territory & $\begin{array}{l}\text { Sampling } \\
\text { period }\end{array}$ & $\begin{array}{l}\text { General conclusion } \\
\text { about the mass } \\
\text { disnersal neriod(s) }\end{array}$ \\
\hline Bagge (1982) & Corixidae & light-trap & Finland & $\begin{array}{l}\text { from May to } \\
\text { October }\end{array}$ & from July to August \\
\hline Behr (1990) & $\begin{array}{l}\text { Hydroporus } \\
\text { spp. }\end{array}$ & artificial habitat & Germany & $\begin{array}{l}\text { from April to } \\
\text { December }\end{array}$ & from June to August \\
\hline Benedek \& Juhász (1972) & Corixidae & light-trap & Hungary & $\begin{array}{l}\text { from March to } \\
\text { November }\end{array}$ & June and September \\
\hline Brown (1954) & Corixidae & light trap & Great Britain & $\begin{array}{l}\text { throughout the } \\
\text { year* }\end{array}$ & spring and early summer \\
\hline Fernando (1958) & Corixidae & $\begin{array}{l}\text { light reflecting } \\
\text { glass trap }\end{array}$ & Great Britain & $\begin{array}{l}\text { from March to } \\
\text { October }\end{array}$ & $\begin{array}{c}\text { spring and from June to } \\
\text { August }\end{array}$ \\
\hline Fernando \& Galbraith (1973) & $\begin{array}{c}\text { aquatic } \\
\text { Coleoptera }\end{array}$ & artificial habitat & Canada & $\begin{array}{l}\text { from April to } \\
\text { October }\end{array}$ & from July to August \\
\hline Landin (1980) & Helophoridae & $\begin{array}{l}\text { light reflecting } \\
\text { glass trap }\end{array}$ & Sweden & $\begin{array}{l}\text { from March to } \\
\text { November }\end{array}$ & from June to August \\
\hline Leston \& Gardner (1953) & Corixidae & light-trap & Great Britain & $\begin{array}{c}\text { from May to } \\
\text { August }\end{array}$ & July \\
\hline Lundkvist et al. (2002) & Dytiscidae & $\begin{array}{l}\text { light reflecting } \\
\text { glass trap }\end{array}$ & Sweden & $\begin{array}{l}\text { from April to mid } \\
\text { October }\end{array}$ & from May to September \\
\hline Miguélez \& Valladares (2008) & $\begin{array}{c}\text { aquatic } \\
\text { Coleoptera }\end{array}$ & Moericke trap & Spain & $\begin{array}{l}\text { from March to } \\
\text { November }\end{array}$ & April to October \\
\hline Nilsson (1997) & $\begin{array}{l}\text { Hydroporus } \\
\text { spp. }\end{array}$ & red car roofs & Sweden & $\begin{array}{c}\text { from May to early } \\
\text { October }\end{array}$ & from June to September \\
\hline Pajunen \& Jansson (1969) & Corixidae & $\begin{array}{l}\text { capture-mark- } \\
\text { recapture }\end{array}$ & Finland & $\begin{array}{l}\text { from May to } \\
\text { October }\end{array}$ & $\begin{array}{c}\text { early spring and late } \\
\text { autumn }\end{array}$ \\
\hline Richard (1958) & Corixidae & light trap & Great Britain & $\begin{array}{l}\text { from April to mid } \\
\text { October }\end{array}$ & $\begin{array}{c}\text { April and from August to } \\
\text { September }\end{array}$ \\
\hline Thomas (1938) & Corixidae & light-trap & Great Britain & $\begin{array}{l}\text { throughout the } \\
\text { year* }\end{array}$ & summer \\
\hline Van der Eijk (1987) & $\begin{array}{l}\text { Gyrinus } \\
\text { marinus }\end{array}$ & $\begin{array}{l}\text { capture-mark- } \\
\text { recapture }\end{array}$ & Netherland & $\begin{array}{l}\text { from April to } \\
\text { December }\end{array}$ & from April to October \\
\hline Weigelhofer et al. (1992) & Corixidae & light-trap & Austria & $\begin{array}{l}\text { from February to } \\
\text { March (next year) }\end{array}$ & from June to September \\
\hline Young (1966) & Corixidae & $\begin{array}{c}\text { direct } \\
\text { observation }\end{array}$ & Great Britain & $\begin{array}{l}\text { from February to } \\
\text { October }\end{array}$ & from March to June \\
\hline
\end{tabular}


Table 4 Review and classification of formerly published results using the scheme. The table shows only those articles, which conform to the requirements of comparability given in Table 3

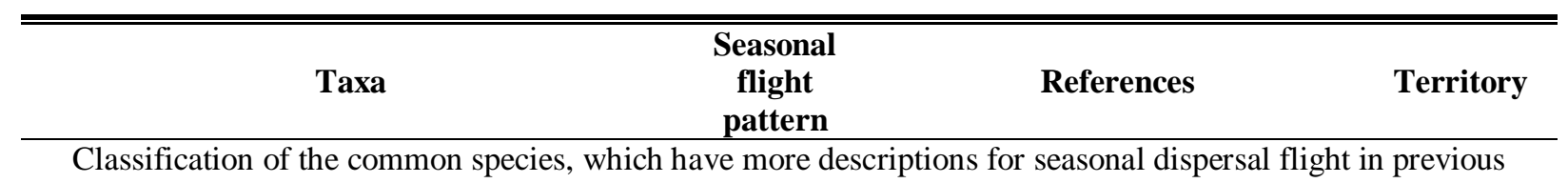

Classification of the common species, which have more descriptions for seasonal dispersal flight in previous papers

\begin{tabular}{|c|c|c|c|}
\hline \multicolumn{4}{|l|}{ Coleoptera } \\
\hline \multicolumn{4}{|l|}{ Dytiscidae } \\
\hline \multirow[t]{3}{*}{ Agabus bipustulatus (Linnaeus, 1767) } & 0-SU-0 & Behr (1990) & Germany \\
\hline & 0-SU-au & Behr (1990) & Germany \\
\hline & 0 -su-AU & Lundkvist et al. (2002) & Sweden \\
\hline \multirow[t]{3}{*}{ Hydroglyphus geminus (Fabricius, 1792) } & $0-\mathrm{SU}-0 *$ & Miguélez \& Valladares (2008) & Spain \\
\hline & $0-S U-a^{*}$ & Miguélez \& Valladares (2008) & Spain \\
\hline & 0 -su-AU & present study & Hungary \\
\hline \multirow[t]{4}{*}{ Hydroporus incognitus Sharp, 1869} & sp-SU-0 & Lundkvist et al. (2002) & Sweden \\
\hline & 0-SU-au & Lundkvist et al. (2002) & Sweden \\
\hline & 0-SU-0 & Behr (1990) & Germany \\
\hline & 0-SU-au & Nilsson (1997) & Sweden \\
\hline \multirow[t]{4}{*}{ Hydroporus planus (Fabricius, 1781) } & SP-su-0 & present study & Hungary \\
\hline & $0-\mathrm{SU}-0$ & Behr (1990) & Germany \\
\hline & 0-SU-0 & Lundkvist et al. (2002) & Sweden \\
\hline & 0-SU-au & Lundkvist et al. (2002) & Sweden \\
\hline \multicolumn{4}{|l|}{ Helophoridae } \\
\hline \multirow[t]{2}{*}{ Helophorus brevipalpis Bedel, 1881} & sp-SU-0 & Miguélez \& Valladares (2008) & Spain \\
\hline & 0-SU-0 & Landin (1980) & Sweden \\
\hline \multicolumn{4}{|l|}{ Hydrophilidae } \\
\hline \multirow[t]{3}{*}{ Anacaena limbata (Fabricius, 1792) } & SP-0-0 & present study & Hungary \\
\hline & sp-SU-0 & Fernando \& Gailbraith (1973) & Canada \\
\hline & sp-SU-au & Fernando \& Gailbraith (1973) & Canada \\
\hline \multicolumn{4}{|c|}{ Classification of the species, which have only one description for seasonal dispersal flight in previous papers } \\
\hline \multicolumn{4}{|c|}{ Coleoptera } \\
\hline \multicolumn{4}{|l|}{ Dytiscidae } \\
\hline Hydroporus morio Aubé, 1838 & 0-Su-au & Nilsson (1997) & Sweden \\
\hline Hydroporus neglectus Schaum, 1845 & 0-SU-0 & Behr (1990) & Germany \\
\hline Hydroporus nigrita (Fabricius, 1792) & 0-SU-0 & Nilsson (1997) & Sweden \\
\hline Hydroporus piceus Stephens, 1828 & $0-S U-a^{*}$ & $\operatorname{Behr}(1990)$ & Germany \\
\hline Hydroporus pubescens (Gyllenhal, 1808) & $\mathrm{sp}-0-\mathrm{AU}^{*}$ & Miguélez \& Valladares (2008) & Spain \\
\hline Hydroporus tristis (Paykull, 1798) & 0-SU-0 & Behr (1990) & Germany \\
\hline \multicolumn{4}{|l|}{ Helophoridae } \\
\hline Helophorus aequalis Thomson, 1868 & 0-SU-0 & $\operatorname{Behr}(1990)$ & Germany \\
\hline Helophorus alternans Gené, 1836 & SP-0-0* & Miguélez \& Valladares (2008) & Spain \\
\hline \multirow[t]{2}{*}{ Helophorus orientalis Motschulsky, 1860} & 0-SU-0 & Fernando \& Gailbraith (1973) & Canada \\
\hline & 0-SU-au & Fernando \& Gailbraith (1973) & Canada \\
\hline Helophorus strigifrons Thomson, 1868 & SP-0-0 & Landin (1980) & Sweden \\
\hline \multicolumn{4}{|l|}{ Hydrophilidae } \\
\hline Anacaena lutescens (Stephens, 1829) & 0-SU-0 & Behr (1990) & Germany \\
\hline \multicolumn{4}{|l|}{ Heteroptera } \\
\hline \multicolumn{4}{|l|}{ Corixidae } \\
\hline Arctocorisa carinata (Sahlberg, 1819) & 0 -su-AU & Pajunen \& Jansson (1969) & Finland \\
\hline Callicorixa producta (Reuter, 1880) & 0 -su-AU & Pajunen \& Jansson (1969) & Finland \\
\hline
\end{tabular}

